\title{
Occurrence of viral haemorrhagic septicaemia virus (VHSV) in wild marine fish species in the coastal regions of Norway
}

\author{
Bjørn E. Brudeseth*, Øystein Evensen \\ National Veterinary Institute, Department of Pathology, PO Box 8156 Dep., 0033 Oslo, Norway
}

\begin{abstract}
This study was aimed at determining the occurrence of viral haemorrhagic septicaemia virus (VHSV) in selected stocks of wild fish species in the coastal regions of Norway. Six cruises were undertaken covering areas which included the coastal regions of northern Norway, the Norwegian Sea, the Barents Sea, and the Skagerrak area down to the Danish border. Collected, pooled samples of internal organs (kidney, spleen and heart) from 8395 fish were examined for the presence of VHSV by inoculation on BF-2 cells. Identification of virus was performed by a standard ELISA procedure with monoclonal antibody IP5B11, which is specific for the VHSV nucleocapsid protein (N-protein). VHSV was isolated from blue whiting and Norway pout in Skagerrak. No positive samples were detected in the northern coastal regions of Norway, the Norwegian Sea, or the Barents Sea. The findings indicate a very low occurrence of VHSV in the coastal regions of Norway. Geographically, the only positive samples were obtained from fish collected in areas where VHSV has previously been found in different species of fish.
\end{abstract}

KEY WORDS: Viral haemorrhagic septicaemia $\cdot$ VHSV $\cdot$ Virus $\cdot$ Marine fish Resale or republication not permitted without written consent of the publisher

\section{INTRODUCTION}

Viral haemorrhagic septicaemia virus (VHSV) is an important viral disease of rainbow trout Oncorhyncus mykiss. Outbreaks are primarily in juvenile freshwater fish (Wolf 1988), although VHSV has been reported in adult seafarmed rainbow trout (Castric \& de Kinkelin 1980, Hørlyck et al. 1984). Disease outbreaks at seastage in these cases are believed to have originated in juvenile fish from freshwater farms. Spread of virus between seawater fish farms has also been observed (Jørgensen 1992).

Outbreaks of VHSV have been detected in other farmed fish species such as turbot Scophthalmus maximus in Germany (Schlotfeldt et al. 1991) and Scotland (Ross et al. 1994). VHSV has also been detected in several wild marine fishes of the Atlantic Ocean such as cod Gadus morhua (Jensen \& Larsen 1979, Jørgensen \& Olesen 1987), haddock Melanogrammus aeglefinus (Mortensen et al. 1999, Smail 2000),

\footnotetext{
*E-mail: bjorn.brudeseth@alpharma.no
}

Norway pout Trisopterus esmarkii, whiting Merlangius merlangus, blue whiting Micromesistius poutassou, and four-bearded rockling Rhinonemus cimbrius (Mortensen et al. 1999) of the Gadidae family, herring Clupea harengus (Dixon et al. 1997, Mortensen et al. 1999) and sprat Sprattus sprattus (Mortensen et al. 1999) of the Clupeidae family, common dab Limanda limanda, flounder Platichthys flesus, plaice Pleuronectes platessa (Skall pers. comm.) of the family Pleuronectidae and lesser argentine Argentina silus (Mortensen et al. 1999) of the Argentinidae family. VHSV has also been detected in wild marine fish in the Pacific Ocean. The first identifications of VHSV were made in returning Chinook salmon Onchorhyncus tshawytscha and Coho salmon $O$. kisutch of the Salmonidae family. In the NE Pacific Ocean, VHSV was reported to be enzootic in cod Gadus macrocephalus and herring Clupea pallasi.

Marine VHSV could be a potential source for infecting farmed fish such as turbot and rainbow trout, but also may pose a risk to halibut Hippoglossus hippoglossus. Halibut have been shown to be susceptible to VHSV, although by injection only (Snow et al. 1999a). 
Results from research cruises performed in the Baltic Sea, Kattegat, Skagerrak and the North Sea indicated that marine VHSV are enzootic to the eastern Baltic Sea. Mortensen et al. (1999) show a low prevalence of this virus in marine fish in the Kattegat, Skagerrak and the North Sea. The European Community has placed VHSV on List 2 of its disease legislation (91/67EEC). The large number of VHSV isolates identified in wild marine fishes raises the problem of determining the coastal zone status for VHSV. VHSV-free areas have been designated on the basis of not identifying VHSV in farmed fishes such as rainbow trout, but potentially infected wild marine fish can habituate or migrate into these areas. Screening of wild marine fish for VHSV is thus important for determining the true status of these VHSV-free areas. No diagnostic method has yet been established to differentiate the marine VHSV from the freshwater VHSV. It is therefore vital to determine the occurrence of marine VHSV in coastal waters around Norway in order to assess the potential risk of infecting farmed marine fish in Norway.

The aim of the study was to determine the occurrence of VHSV in the coastal regions of Norway, the Norwegian Sea, the Barents Sea and the Skagerrak in selected wild populations of fish with emphasis on the Gadidae and Clupeidae families.

\section{MATERIALS AND METHODS}

Fish sampling. Fish samples were collected from 6 cruises undertaken during the 1997-1999 period. - Cruise 1 (April 1997): In the Norwegian Sea, focusing on sampling of herring post-spawning. The fishing was performed as pelagic trawling with 1 to $2 \mathrm{~h}$ trawling time.

- Cruise 2 (July-August 1997): In the Norwegian Sea. Focusing on sampling of herring. The fishing was performed as pelagic trawling with 1 to $2 \mathrm{~h}$ trawling time. - Cruise 3 (June-August 1998): In the coastal region of southern Norway. Focusing on sampling of juvenile cod. The fish were caught by beach seine at different locations along the coast.

- Cruise 4 (September-October 1998): In the Barents Sea, focusing on sampling of juvenile cod and haddock. The fishing was performed as pelagic and demersal trawling with 1 to $2 \mathrm{~h}$ trawling time.

- Cruise 5 (March 1999): In the northern coastal region of Norway, focusing on sampling of adult cod and haddock. The fishing was performed as demersal trawling with 0.5 to $2 \mathrm{~h}$ trawling time.

- Cruise 6 (October 1999): In Skagerrak. This cruise focused on sampling of fish in the Gadidea family. The fishing was performed as demersal trawling with 0.5 to $2 \mathrm{~h}$ trawling time.
Sampling of organ specimens. Organ specimens of kidney, spleen and heart from individual fish $(>5 \mathrm{~cm}$ length) were sampled and processed (as described below) onboard the research vessel. Organ material of 10 fish (maximum) of 1 species was placed in 1 plastic tube containing Eagle's minimum essential medium with Earle's balanced salt solution (EBSS), supplemented with $16.4 \mathrm{mM}$ Tris-buffer, $5.3 \mathrm{mM} \mathrm{NaHCO}{ }_{3}$, $10 \%$ fetal bovine serum (FBS), $4 \mathrm{mM}$ L-glutamine and $100 \mu \mathrm{g} \mathrm{ml}^{-1}$ gentamicin (transport medium). One pool consisted of $\sim 2 \mathrm{~g}$ of organ material. Juvenile fish or small fish $(<5 \mathrm{~cm}$ length) were sampled as either whole, or whole with an incision made ventral to the head and dorsal to the anal fin. For each pool, the location of the haul and the fish species were recorded along with the length and sex of each individual fish.

Fish with external lesions were treated separately and organ samples included skin and internal organs (kidney, spleen and heart). Skin and internal organs were taken from fish in an aseptic environment using sterile scissors, forceps and scalpels. The samples were transferred to plastic tubes containing transport medium. All samples were stored at $-30^{\circ} \mathrm{C}$ onboard the vessel. Following completion of the cruise, the samples were transported in a frozen condition to the laboratory and kept at $-80^{\circ} \mathrm{C}$ until thawed for virological examination.

Cell culture. Bluegill sunfish cells (BF-2, ATCC CCl 91) were used for the detection of VHSV in sampled material. The cells were cultured in closed flasks in Eagle's minimum essential medium with EBSS supplemented with $15 \mathrm{mM}$ HEPES (4-[2-hydroxyethyl] -1-piperazine-ethanesulphonic acid), $5.3 \mathrm{mM} \mathrm{NaHCO}_{3}$, $10 \%$ fetal bovine serum (FBS), $4 \mathrm{mM}$ L-glutamine and $50 \mu \mathrm{g} \mathrm{ml}^{-1}$ gentamicin and incubated at $20^{\circ} \mathrm{C}$. For virus propagation in tissue culture plates, the same medium was used, except that HEPES was replaced with 16.4 mM Tris-buffer.

Virological examination and identification. Pooled samples were diluted 1/10 in transport medium. Skin samples from individual fish with lesions were also diluted 1/10. All samples were homogenised using a mortar, and kept on ice during the procedure. The homogenate was centrifuged $\left(1500 \mathrm{~g}, 4^{\circ} \mathrm{C}, 15 \mathrm{~min}\right.$, Beckmann GS-6R). Supernatant (1.5 ml) was added to duplicate tubes, and stored at $-80^{\circ} \mathrm{C}$. The supernatant was added to BF-2 cells cultured on 24 well plates ( 20 to $48 \mathrm{~h}$ old). Supernatant from skin samples was sterilefiltered using a syringe and a $0.45 \mu \mathrm{m}$ filter. The final dilution of tissue material in the cell culture medium was 1:100 and 1:1000. The inoculated cells were incubated at $15^{\circ} \mathrm{C}$ for $7 \mathrm{~d}$. Inoculated cell cultures were inspected for up to $7 \mathrm{~d}$ after inoculation for the occurrence of cytopathogenic effect (CPE) in the primary incubation. Cell culture medium was then passed to fresh ( 20 to $48 \mathrm{~h}$ 
old) BF-2 cells cultured on 24 well plates. Inoculated cells were inspected for the occurrence of CPE during the secondary incubation period lasting up to $7 \mathrm{~d}$ after inoculation. Identification of VHSV was performed by a standard ELISA technique using monoclonal antibody IP5B11, which is specific for the nucleocapsid protein (N-protein) of VHSV (Olesen \& Jørgensen 1991).

\section{RESULTS}

\section{Fish sampling}

For fish species sampled, see Table 1. Cruise 1 focused on sampling of post-spawning herring and blue whiting in the Norwegian Sea. Both are target species for marine VHSV. On this cruise, 791 fish from
3 different species were sampled from 13 hauls. The sampled fish consisted mainly of herring and blue whiting and all samples were negative for VHSV. One herring was found to be infected with Ichthyophonus hoferi, resulting in skin lesions. Pseudobranch 'tumors' caused by X-cell parasites (Morrison et al. 1982) were detected in 1 blue whiting.

Cruise 2 in the Norwegian Sea focused on the same species as Cruise 1 (Fig. 1). A total of 1156 fish of 7 different species from 42 hauls were sampled. They consisted mainly of herring and blue whiting. Ichthyophonus hoferi was found to infect 15 herring, resulting in skin lesions. One mackerel was found with skin lesions. When examined for VHSV in cell culture, all samples from this cruise were found to be negative.

Cruise 3 in the coastal region of southern Norway sampled 2531 fish of 21 species from 21 different locations,

Table 1. Marine fish species sampled for research cruises 1 to 6, coastal regions of Norway

\begin{tabular}{|c|c|c|c|c|c|c|c|c|}
\hline Area (cruise no.): & $\begin{array}{l}\text { Norwegian } \\
\text { Sea (1) }\end{array}$ & $\begin{array}{l}\text { Norwegian } \\
\text { Sea }(2)\end{array}$ & $\begin{array}{l}\text { Norwegian } \\
\text { south coast ( } 3 \text { ) }\end{array}$ & $\begin{array}{l}\text { Barents } \\
\text { Sea }(4)\end{array}$ & $\begin{array}{l}\text { Lofoten } \\
\text { area (5) }\end{array}$ & $\begin{array}{l}\text { Skagerrak/ } \\
\text { North Sea (6) }\end{array}$ & All 6 & cruises \\
\hline $\begin{array}{l}\text { Family } \\
\text { Species }\end{array}$ & $\begin{array}{l}\text { No. } \\
\text { fish }\end{array}$ & $\begin{array}{l}\text { No. } \\
\text { fish }\end{array}$ & $\begin{array}{l}\text { No. } \\
\text { fish }\end{array}$ & $\begin{array}{l}\text { No. } \\
\text { fish }\end{array}$ & $\begin{array}{l}\text { No. } \\
\text { fish }\end{array}$ & $\begin{array}{l}\text { No. } \\
\text { fish }\end{array}$ & $\begin{array}{l}\text { No. } \\
\text { fish }\end{array}$ & $\begin{array}{l}\text { No. } \\
\text { VHSV }\end{array}$ \\
\hline \multicolumn{9}{|l|}{ Clupeidae } \\
\hline Herring Clupea harengus & 377 & 274 & 1 & 180 & & 120 & 952 & \\
\hline Sprat Sprattus sprattus & & & 440 & & & & 440 & \\
\hline \multicolumn{9}{|l|}{ Anguillidae } \\
\hline Eel Anguilla anguilla & & & 1 & & & & 1 & \\
\hline \multicolumn{9}{|l|}{ Argentinidae } \\
\hline Argentine Argentina silus & & 10 & & & & & 10 & \\
\hline \multicolumn{9}{|l|}{ Gadidae } \\
\hline Cod Gadus morhua & & & 490 & 200 & 536 & 43 & 1269 & \\
\hline $\begin{array}{l}\text { Haddock Melanogrammus } \\
\text { aeglefinus }\end{array}$ & & 8 & & 340 & 240 & 200 & 788 & \\
\hline Pollack Pollachius pollachios & & & 5 & & & & 5 & \\
\hline Saithe Pollachius virens & & & 2 & & 190 & 2 & 194 & \\
\hline $\begin{array}{l}\text { Whiting Merlangius } \\
\text { merlangus }\end{array}$ & & & 18 & & & & 18 & \\
\hline $\begin{array}{l}\text { Blue whiting Micromesistius } \\
\text { poutassou }\end{array}$ & 410 & 775 & & 3 & 4 & 860 & 2052 & 1 \\
\hline $\begin{array}{l}\text { Norway pout Trisopterus } \\
\text { esmarkii }\end{array}$ & & & & & 380 & 40 & 420 & 1 \\
\hline Torsk Brosme brosme & & & & & 35 & & 35 & \\
\hline Ling Molva molva & & & & & 4 & & 4 & \\
\hline $\begin{array}{l}\text { Four-bearded rockling } \\
\text { Rhinonemus cimbrius }\end{array}$ & & & & & & 25 & 25 & \\
\hline $\begin{array}{l}\text { Lophiidae } \\
\text { Angler/monkfish } \\
\text { Lophius piscatorius }\end{array}$ & & & & & 2 & & 2 & \\
\hline \multicolumn{9}{|l|}{ Scombridae } \\
\hline Mackerel Scomber scombrus & & 31 & & & & & 31 & \\
\hline \multicolumn{9}{|l|}{ Carangidae } \\
\hline $\begin{array}{l}\text { Horse-mackerel } \\
\text { Trachurus trachurus }\end{array}$ & & 7 & 10 & & & & 17 & \\
\hline
\end{tabular}


Table 1 (continued)

\begin{tabular}{|c|c|c|c|c|c|c|c|c|}
\hline Area (cruise no.): & $\begin{array}{l}\text { Norwegian } \\
\text { Sea (1) }\end{array}$ & $\begin{array}{l}\text { Norwegian } \\
\text { Sea (2) }\end{array}$ & $\begin{array}{l}\text { Norwegian } \\
\text { south coast ( } 3 \text { ) }\end{array}$ & $\begin{array}{l}\text { Barents } \\
\text { Sea (4) }\end{array}$ & $\begin{array}{l}\text { Lofoten } \\
\text { area (5) }\end{array}$ & $\begin{array}{l}\text { Skagerrak/ } \\
\text { North Sea (6) }\end{array}$ & All 6 & cruises \\
\hline $\begin{array}{l}\text { Family } \\
\text { Species }\end{array}$ & $\begin{array}{l}\text { No. } \\
\text { fish }\end{array}$ & $\begin{array}{l}\text { No. } \\
\text { fish }\end{array}$ & $\begin{array}{l}\text { No. } \\
\text { fish }\end{array}$ & $\begin{array}{l}\text { No. } \\
\text { fish }\end{array}$ & $\begin{array}{l}\text { No. } \\
\text { fish }\end{array}$ & $\begin{array}{l}\text { No. } \\
\text { fish }\end{array}$ & $\begin{array}{l}\text { No. } \\
\text { fish }\end{array}$ & $\begin{array}{l}\text { No. } \\
\text { VHSV }\end{array}$ \\
\hline \multicolumn{9}{|l|}{ Gobiidae } \\
\hline $\begin{array}{l}\text { Two-spotted goby } \\
\text { Gobiusculus flavescens }\end{array}$ & & & 300 & & & & \multicolumn{2}{|l|}{300} \\
\hline $\begin{array}{l}\text { Sand goby Pomatoschistus } \\
\text { minutus }\end{array}$ & & & 260 & & & & \multicolumn{2}{|l|}{260} \\
\hline Black goby Gobius niger & & & 140 & & & & \multicolumn{2}{|l|}{140} \\
\hline $\begin{array}{l}\text { Painted goby Pomatoschistus } \\
\text { pictus }\end{array}$ & & & 260 & & & & \multicolumn{2}{|l|}{260} \\
\hline $\begin{array}{l}\text { Transparent goby } \\
\text { Aphya minuta }\end{array}$ & & & 290 & & & & \multicolumn{2}{|l|}{290} \\
\hline $\begin{array}{l}\text { Crystall goby } \\
\text { Crystallogobius linearis }\end{array}$ & & & 50 & & & & \multicolumn{2}{|l|}{50} \\
\hline \multicolumn{9}{|l|}{ Labridae } \\
\hline $\begin{array}{l}\text { Goldsinny Ctenolabrus } \\
\text { rupestris }\end{array}$ & & & 11 & & & & \multicolumn{2}{|l|}{11} \\
\hline $\begin{array}{l}\text { Ballan wrasse } \\
\text { Labrus bergylta }\end{array}$ & & & 5 & & & & \multicolumn{2}{|l|}{5} \\
\hline $\begin{array}{l}\text { Corkwing wrasse } \\
\text { Symphodus melops }\end{array}$ & & & 5 & & & & \multicolumn{2}{|l|}{5} \\
\hline \multicolumn{9}{|l|}{ Pleuronectidae } \\
\hline Flounder Platichthys flesus & & & 8 & & & & \multicolumn{2}{|l|}{8} \\
\hline $\begin{array}{l}\text { Long rough dab } \\
\quad \text { Hippoglossoides platessoides }\end{array}$ & & & & 90 & 24 & & \multicolumn{2}{|l|}{114} \\
\hline $\begin{array}{l}\text { Common dab Limanda } \\
\text { limanda }\end{array}$ & & & & & 42 & 6 & \multicolumn{2}{|l|}{48} \\
\hline $\begin{array}{l}\text { Witch Glyptocephalus } \\
\text { cynoglossus }\end{array}$ & & & & & 1 & 84 & \multicolumn{2}{|l|}{85} \\
\hline Lemon sole Microstomus kitt & & & & & 16 & 2 & \multicolumn{2}{|l|}{18} \\
\hline Plaice Pleuronectes platessa & & & & & 105 & 8 & \multicolumn{2}{|l|}{113} \\
\hline $\begin{array}{l}\text { Halibut Hippoglossus } \\
\text { hippoglossus }\end{array}$ & & & & & 3 & & \multicolumn{2}{|l|}{3} \\
\hline Soleidae & & & & & & & \multirow{2}{*}{\multicolumn{2}{|c|}{2}} \\
\hline Common sole Solea vulgaris & & & 2 & & & & & \\
\hline $\begin{array}{l}\text { Salmonidae } \\
\text { Trout Salmo trutta }\end{array}$ & & & 2 & & & & \multicolumn{2}{|l|}{2} \\
\hline $\begin{array}{l}\text { Osmeridae } \\
\text { Capelin Mallotus villosus }\end{array}$ & & & & 280 & & & \multicolumn{2}{|l|}{280} \\
\hline $\begin{array}{l}\text { Gasterostidae } \\
\text { Three-spined stickleback } \\
\text { Gasterosteus aculeatus }\end{array}$ & & & 52 & & & & \multicolumn{2}{|l|}{52} \\
\hline $\begin{array}{l}\text { Anarhichadidae } \\
\text { Wolf fish Anarhichas lupus } \\
\text { Spotted cat (Northern wolf) fish } \\
\text { Anarhichas minor }\end{array}$ & & & & 1 & 30 & & \multicolumn{2}{|l|}{1} \\
\hline $\begin{array}{l}\text { Cyclopteridae } \\
\text { Lumpsucker Cyclopterus } \\
\quad \text { lumpus }\end{array}$ & 4 & 51 & & & & & \multicolumn{2}{|l|}{55} \\
\hline Total fish sampled & 791 & 1156 & 2352 & 1094 & 1612 & 1390 & \multirow{2}{*}{\multicolumn{2}{|c|}{8395}} \\
\hline Total samples & 84 & 120 & 283 & 110 & 201 & 156 & & \\
\hline
\end{tabular}




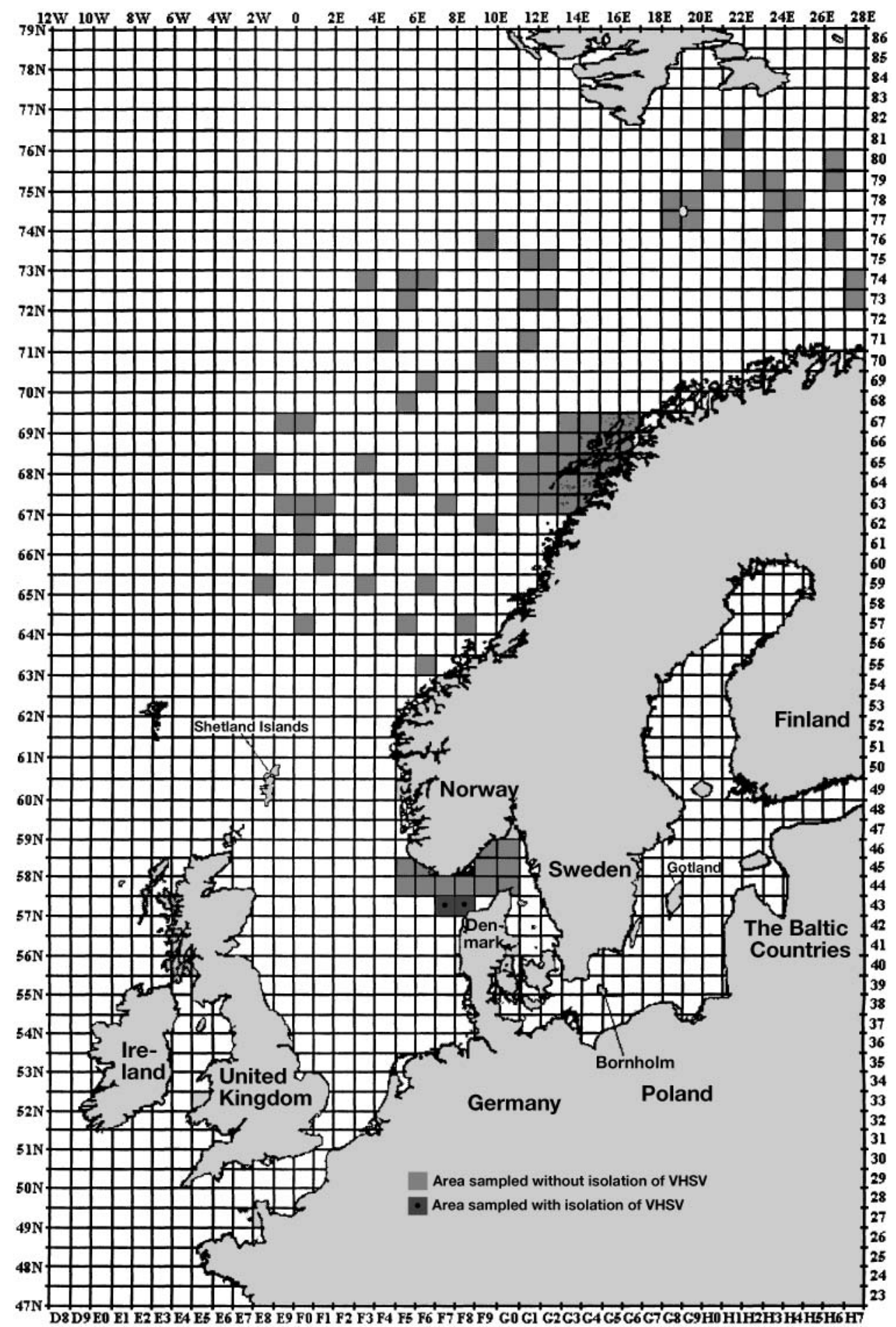

Fig. 1. Sampling of fish in the coastal regions of Norway

the major species sampled being juvenile cod. One sprat was found to be infected with Ichthyophonus hoferi, resulting in skin lesions. Three whiting were detected with skin lesions. When examined for VHSV in cell culture, all samples from this cruise were found to be negative.
Cruise 4 in the Barents Sea sampled 1094 fish of 6 species from 17 hauls. Five herring were found infected with Ichthyophonus hoferi, resulting in skin lesions. When examined for VHSV in cell culture, all samples from this cruise were found to be negative. 
Cruise 5 in the coastal region of Lofoten in Norway sampled 1612 fish of 15 species from 18 hauls. Two cod were found to have skin lesions. Pseudobranch 'tumors' caused by X-cell parasites were detected in 1 cod. One wolf fish was detected with skin lesions. When examined for VHSV in cell culture, all samples from this cruise were found to be negative.

Cruise 6 in the Skagerrak sampled 1390 fish of 11 species from 38 hauls. VHSV was isolated from 1 pooled sample of blue whiting and 1 pooled sample of Norway pout. Skin samples from fish with lesions were all negative for VHSV. Three herring were found with skin lesions caused by Ichthyophonus hoferi.

\section{DISCUSSION}

The main conclusion that can be drawn from this study is that VHSV occurs at a very low prevalence in marine fish species in the coastal regions of Norway. Only 2 samples were found to be positive out of 954 skin and internal organ samples collected from 8395 fish. The positive samples were from Norway pout and blue whiting in the Skagerrak. No marine VHSV was detected in wild marine fish species sampled in the coastal regions in northern Norway, the Norwegian Sea or the Barents Sea.

This study is in support of previous findings (Mortensen et al. 1999) showing the presence of marine VHSV in Norway pout and blue whiting in the Skagerrak/North Sea. In the coastal regions of northern Norway, the Norwegian Sea and the Barents Sea (Cruises 1, 2, 4 and 5), marine VHSV-susceptible species of the Atlantic such as cod (Jensen \& Larsen 1979, Jørgensen \& Olesen 1987), herring (Dixon et al. 1997), haddock (Smail 2000), blue whiting, Norway pout, four-bearded rockling, lesser argentine (Mortensen et al. 1999) and common dab, flounder and plaice (Skall pers. comm.) were sampled and no virus was detected in specimens processed.

Cruises 3 and 4 included sampling of juvenile fish, since there are indications for a higher prevalence of VHSV in juvenile fish compared with adult fish. These assumptions were based on the fact that freshwater VHSV primarily causes disease in juvenile rainbow trout (Wolf 1988). Furthermore, studies in pacific herring Clupea harengus pallasi indicate a higher prevalence of marine VHSV in juveniles compared with adults (Hershberger et al. 1999). Similarly, outbreaks of VHSV in adult turbot (1.1 to $1.9 \mathrm{~kg}$ ) caused $6 \%$ mortality (Munro 1996), while experimental bath challenge with the same isolate caused $<71 \%$ mortality in juvenile turbot of mean weight $8 \mathrm{~g}$ (Snow \& Smail 1999). Fish collected during Cruise 3 were all negative for VHSV and this included 490 juvenile cod and
440 juvenile sprat that were sampled in the coastal area of southern Norway. This is despite the fact that marine VHSV has previously been detected in cod in this area, and marine VHSV is widespread in sprat throughout the Baltic Sea (Mortensen et al. 1999). However, the referred study gave no indication of a higher occurrence in juvenile fish compared with that of adults in the Norwegian coastal areas of the Skagerrak. Similarly, all samples resulting from Cruise 4 in the Barents Sea, where juvenile fish of cod, haddock and herring were sampled, proved negative. Therefore, collection and examination of individuals of the most susceptible physiological state of fish of these families in the coastal areas of Norway gave indication of a very low prevalence of VHSV infection. However, in studies performed by King et al. (2001b), 19293 wild fish were sampled and 21 VHSV samples were found. Seventeen of the 21 isolates were identified in Norway pout, representing 2535 out of the 19293 fish examined; of the remaining 16758 fish, only 4 fish were found positive. This demonstrates that although a low occurrence of VHSV is detected in the present study, which is also based on fewer fish, it does not exclude the possibility that VHSV-infected fish can be found in coastal areas in northern Norway. The use of cell culture for detecting VHSV is considered a sensitive method, but labour intensive methods and the use of pooled samples is a practical approach towards reducing the amount of labour that is required to screen the high number of samples. Obviously, when pooling organ samples from 10 fish, it is likely that this will lower the sensitivity of the test, which again means that we cannot rule out the possibility of very low carrier levels not being detected.

The selected species of wild marine fish that were sampled during the cruises were of the Gadidae and Clupeidae family. Three fish species of these families, such as herring, Arctic cod, and Arctic haddock, migrate throughout the Barents Sea, Norwegian Sea and the northern coastal regions of Norway. Although these fish species were sampled over a large area, they belong to the same population (Hamre \& Aglen 1995). Previous studies have shown a high frequency of VHSV in herring sampled in the Baltic sea (Mortensen et al. 1999), and VHSV has also been detected in Atlantic herring in the English Channel (Dixon et al. 1997). A study has also shown Pacific herring to be highly susceptible to VHSV (Kocan et al. 1998). The negative findings reported herein for the ScandoAtlantic population of herring indicate a low occurrence or non-existence of marine VHSV within these populations. This might be explained by a very limited interaction between the Scando-Atlantic and North Sea population of herring (Hamre \& Aglen 1995). For other fish species, data are scarce as regards 
interaction or contact between populations. Other reasons might be that the low water temperatures in the northern area can have an impact, however, marine VHSV has been detected on the Pacific coast of Alaska (Meyers et al. 1994) where seawater temperatures comparable with the northern part of Norway are found. In general, this study indicates that marine VHSV infection occurs at a low frequency in marine fish of the Clupeidae and Gadidae family in the Norwegian Sea, Barents Sea and the Northern coastal regions.

VHSV has been demonstrated to be a threat to farmed fish such as turbot (Castric \& de Kinkelin 1984, Schlotfeldt 1991, Ross et al. 1994, Snow \& Smail 1999), while halibut and cod seem to be less susceptible to marine VHSV (Snow et al. 1999a, 2000). Challenge experiments in juvenile cod with marine VHSV isolates from wild-caught Atlantic cod show no mortality following bath challenge. In contrast, challenge by intraperitoneal injection caused clinical disease and a mortality of $80 \%$ in juvenile cod (Snow et al. 2000). Nucleotide sequencing analysis has demonstrated similarity between a virus causing epizootic in farmed turbot and isolates from wild fish of the North Sea (Stone et al. 1997, Snow et al. 1999b). VHSV isolates from wild herring in Skagerrak have been demonstrated to cause mortality in turbot by experimental infection (King et al. 2001a). Based on this study, it seems reasonable to conclude that wild stocks of marine fish from Norwegian waters do not pose a major threat to farmed fish, either through direct contact or when used as feed. The suggestion is however that VHSV-susceptible fish species of the Clupeidae, Gadidae and Pleuronectidae families should not be used as untreated fish feed for marine fish.

Acknowledgements. The authors are grateful to the Institute of Marine Research for giving us the opportunity to participate in several of their research cruises. The authors thank Birgit Dannevig for valuable scientific advice and for assistance during cultivation of the virus. Helle Frank Skall is also thanked for help with the map figure. Funded by EU FAIRCT-96-1594.

\section{LITERATURE CITED}

Castric J, de Kinkelin P (1980) Occurrence of viral haemorrhagic septicaemia in rainbow trout Salmo gairdneri Richardson reared in sea water. J Fish Dis 3:21-27

Castric J, de Kinkelin P (1984) Experimental study of the susceptibility of two marine fish species, seabass (Dicentrarchus labrax) and turbot (Scophthalmus maximus), to viral haemorrhagic septicaemia. Aquaculture 41:203-212

Dixon PF, Feist S, Kehoe E, Parry L, Stone DM, Way K (1997) Isolation of viral haemorrhagic septicaemia virus from Atlantic herring Clupea harengus from the English channel. Dis Aquat Org 30:81-89
Hamre J, Aglen E (1995) Herring. In: Torsvik N, Mortensen S, Nedreaas KH (eds) Fisheries biology. The Agricultural Publisher, p 61-77

Hershberger PK, Kocan RM, Elder NE, Meyers TR, Winton JR (1999) Epizootiology of viral haemorrhagic septicaemia virus in Pacific herring from the spawn-on-kelp fishery in Prince William Sound, Alaska, USA. Dis Aquat Org 37:23-31

Hørlyck V, Mellergård S, Dalsgaard I, Jørgensen PEV (1984) Occurrence of VHSV in Danish maricultured rainbow trout. Bull Eur Fish Pathol 4(1):11-13

Jensen NJ, Larsen JL (1979) The Ulcus-syndrome in cod (Gadus Morhua). III. A preliminary virological report. Nordisk Vet Med 31:436-442

Jørgensen PEV (1992) Recent advances in surveillance and control of viral haemorrhagic septicaemia (VHS) of trout. In: Kimura T (ed) Salmonid diseases. Proc OJI Int Symp Salmonid Diseases. Hokkaido University Press, Sapporo, p 60-71

Jørgensen PEV, Olesen NJ (1987) Cod ulcus syndrome rhabdovirus is indistinguishable form the Egtved (VHSV). Bull Eur Fish Pathol 7(3):73-74

King JA, Snow M, Skall HF, Raynard RS (2001a) Experimental susceptibility of Atlantic salmon Salmo salar and turbot Scophthalmus maximus to European freshwater and marine isolates of viral haemorrhagic septicaemia virus. Dis Aquat Org 47:25-31

King JA, Snow M, Smail DA, Raynard RS (2001b) Distribution of viral haemorrhagic septicaemia virus in wild fish species of the North Sea, north east Atlantic Ocean and Irish Sea. Dis Aquat Org 47:81-86

Kocan R, Bradley M, Elder N, Meyers T, Batts B, Winton J (1997) North American strain of viral haemorrhagic septicaemia virus is highly pathogenic for laboratory-reared Pacific herring. J Aquat Anim Health 9:279-290

Meyers TR, Short S, Lipson K, Batts WN, Winton JR, Wilcock J, Brown E (1994) Association of viral haemorrhagic septicaemia virus with epizootic haemorrhages of the skin in Pacific herring Clupea harengus pallasi from Prince William Sound and Kodiak Island, Alaska, USA. Dis Aquat Org 19:27-37

Morrison CMG, Shum RG, Appy P, Odense, Annand C (1982) Histology and prevalence of X-cell lesions in Atlantic cod (Gadus Morhua). Can J Fish Aquat Sci 39:1519-1530

Mortensen HF, Heuer OE, Lorenzen N, Otte L, Olesen NJ (1999) Isolation of viral haemorrhagic septicaemia virus (VHSV) from wild marine fish species in the Baltic Sea, Kattegat, Skagerrak and the North Sea. Vir Res 63:95-106

Munro AS (1996) Report on the first recorded outbreak of viral haemorrhagic septicaemia (VHS) in Great Britain and subsequent actions to contain, eradicate and investigate the origins of the infection. Scottish Aquaculture Research Report Number 3. The Scottish Office of Agriculture, Environment and Fisheries Department, Aberdeen

Olesen NJ, Jørgensen PEV (1991) Rapid detection of viral haemorrhagic septicaemia virus in fish by ELISA. J Appl Ichtyol 7:183-186

Ross K, McCarthy U, Huntly PJ, Wood BP, Stuart D, Rough EI, Smail DA, Bruno DW (1994) An outbreak of viral haemorrhagic septicaemia (VHS) in turbot (Scophthalmus maximus) in Scotland. Bull Eur Assoc Fish Pathol 14(6):213-214

Schlotfeldt HJ, Ahne W, Vestergård-Jørgensen PE, Glende W (1991) Occurrence of viral haemorrhagic septicaemia virus in turbot (Scophthalmus maximus) - a natural outbreak. Bull Eur Assoc Fish Pathol 11(3):105-107 
Smail DA (2000) Isolation and identification of viral haemorrhagic septicaemia (VHS) from cod Gadus Morhua with the ulcus syndrome and from haddock Melanogrammus aeglefinus having skin haemorrhages in the North Sea. Dis Aquat Org 41:231-235

Snow M, Smail DA (1999) Experimental susceptibility of turbot Scophthalmus maximus to viral haemorrhagic septicaemia virus isolated from cultivated turbot. Dis Aquat Org 38:163-168

Snow M, Bowden TJ, Bricknell IR (1999a) Susceptibility of Atlantic halibut (Hippoglossus hippoglossus) to viral haemorrhagic septicaemia virus. 9th Int Conf Dis Fish and Shellfish, Rhodes, p 176

Snow M, Cunningham CO, Melvin WT, Kurath G (1999b) Analysis of the nucleoprotein gene identifies distinct

Editorial responsibility: Jo-Ann Leong,

Corvallis, Oregon, USA lineages of viral haemorrhagic septicaemia virus (VHSV) within the European marine environment. Vir Res 63:35-44 Snow M, Cunningham CO, Bricknell IR (2000) Susceptibility of juvenile Atlantic cod Gadus Morhua to viral haemorrhagic septicaemia virus isolated from wild-caught Atlantic cod. Dis Aquat Org 41:225-229

Stone DM, Way K, Dixon PF (1997) Nucleotide sequence of the glycoprotein gene of viral haemorrhagic septicaemia (VHS) from different geographical areas: a link between VHSV in farmed fish species and viruses isolated from North Sea cod (Gadus morhua L.). J Gen Virol 78: 1319-1326

Wolf K (ed) (1988) Viral hemorrhagic septicaemia. In: Fish viruses and fish viral diseases. Cornell University Press, New York, p 217-249

Submitted: August 24, 2001; Accepted: April 3, 2002

Proofs received from author(s): September 17, 2002 